\title{
PEMANFAATAN THERAPY MUSIK RELIGI ISLAM TERHADAP INTENSITAS NYERI BERSALIN DAN PENURUNAN KECEMASAN PERSALINAN
}

\author{
Ester Simanullang ${ }^{1}$, Lusiatun ${ }^{2}$, \\ Ngarap Muliana Romaito Harahap ${ }^{3}$, Oni Kurnia ${ }^{4}$ \\ ${ }^{1,2}$ STIKes Mitra Husada Medan \\ ${ }^{3,4}$ STIKes Mitra Husada Medan \\ *correspondence author: Handphone: 081269706911, \\ E-mail: 1estersimanullang13.es@ gmail.com, ${ }^{2}$ lusiatun12@gmail.com, ${ }^{4}$ onikurnia21@ gmail.com
}

\begin{abstract}
Abstrak
Secara fisiologi nyeri persalinan mulai timbul pada persalinan kala I fase laten dan fase aktif, pada fase laten terjadi pembukaan sampai $3 \mathrm{~cm}$. Nyeri disebabkan oleh kontraksi uterus dan dilatasi serviks. Makin lama nyeri yang dirasakan akan bertambah kuat, puncak nyeri terjadi pada fase aktif, di mana pembukaan lengkap sampai $10 \mathrm{~cm}$. Intensitas nyeri selama persalinan mempengaruhi kondisi psikologis ibu, proses persalinan, dan kesejahteraan janin

Pada pengabdian masyarakat yang Kegiatan Pengabdian masyarakat ini berdasarkan hasil kerjasama dari pihak terkait STIKes Mitra Husada Medan dan Puskesmas Sawit Seberang. Pengabdian masyarakat terkait dengan pemberian Therapy music religi islam melihat banyaknya persalinan yang terlaksana di Puskesmas Sawit Seberang dan yang mayoritas masyarakat muslim.

Pada kegiatan ini dilakukan langkah-langkah yang sistematis berupa : 1. Identifikasi jumlah persalinan normal yang berlangsung. 2. Anamnesa pada ibu hamil dalam persalinan Kala I. 3. Memberikan informed consent pada ibu yang akan dilakukan pengabdian masyarakat. 4. Pemberian therapy music religi islam dalam persalinan kala I dan mensosialisasikan serta memberikan penyuluhan singkat kepada keluarga mengenai therpy yang diberikan. Hasil disimpulkan bahwa ada perubahan yang terjadi setelah melakukan terapi music seperti adanya perasaan nyaman, santai, rileks dan tidak merasa cemas pada ibu yang bersalin. Dan dianjurkan kedepan bisa memberikan therapy musik lainnya.
\end{abstract}

Kata kunci: Therapy Musik Religi Islam, Nyeri Bersalin, Kecemasan Bersalin

\section{Pendahuluan}

Persalinan adalah suatu proses pengeluaran hasil konsepsi (janin dan uri), yang dapat hidup ke dunia luar, dari rahim melalui jalan lahir atau dengan jalan lain Selama persalinan, rahim berkontraksi dan mendorong bayi ke bawah sampai ke leher rahim. Dorongan ini membuka leher rahim. Setelah leher rahim mencapai pembukaan lengkap, kontraksi dan dorongan ibu akan menggerakkan si bayi ke bawah dan keluar beberapa hari Berat dari kepala bayi ketika bergerak ke bawah saluran lahir juga menyebabkan tekanan.

Proses pengeluaran hasil konsepsi yang dapat hidup dari uterus melalui vagina ke dunia luar disebut juga persalinan. Proses ini dibagi menjadi empat kala, yaitu kala I, kala pembukaan servik atau jalan lahir, dimana Servik membuka sampai terjadi pembukaan 10 $\mathrm{cm}$. Kala II disebut kala Pengeluaran janin.
Kala III disebut kala pelepasan dan pengeluaran plasenta. Kala IV observasi dini terhadap perdarahan post partum (Mochtar Rustam, 2011).

Persalinan dimulai bila timbul his dan mengeluarkan lendir yang bercampur darah. Lendir yang bercampur darah ini terjadi karena servik mulai membuka atau mendatar, sedangkan darahnya berasal dari pembuluh darah kapiler yang berada disekitar kanalis servikalis karena pergeseran ketika servik mendatar dan terbuka (Mochtar Rustam, 2011).

Nyeri merupakan suatu hal secara psikologis yang timbul pada persalinan, namun banyak wanita yang merasakan nyeri tersebut lebih parah dari seharusnya karena banyak dipengaruhi oleh lingkungan, umur, jenis kelamin, kelelahan, budaya, dan pengalaman 
masa lalu, dimana rasa takut menimbulkan ketegangan dan kepanikan yang menyebabkan otot-otot menjadi kaku dan akhirnya menyebabkan rasa sakit Persepsi nyeri yang dirasakan seseorang berbeda-beda dan tergantung adaptasinya selama proses persalinan mendapatkan indeks nyeri persalinan berdasarkan McGillPainIndeks (MPI) dengan skala indeks 0-50 untuk primipara (38), multipara (30), amputasi (25), dan kanker (28).

Terapi musik religi islammerupakan salah satu metode untuk teknik relaksasi yang jarang diaplikasikan di dalam praktek keperawatan maternitas, padahal terapi musik religi islammerupakan salah satu teknik distraksi yang efektif yang dapat menurunkan nyeri fisiologi, stress dan nyeri bersalin dengan mengalihkan perhatian seseorang dari nyeri Disamping itu musik religi islamjuga berfungsi sebagai pengontrol dan merupakan teknik untuk menimbulkan kenyamanan lingkungan saat wanita melahirkan diruang bersalin. Music Therapy dapat meningkatkan, memulihkan, dan memelihara kesehatan fisik, mental, emosional, sosial dan spiritual. Hal ini disebabkan musik

\section{Bahan dan Metode}

Pada pengabdian masyarakat yang Kegiatan Pengabdian masyarakat ini berdasarkan hasil kerjasama dari pihak terkait antara Sekolah Tinggi Ilmu Kesehatan (STIKes) Mitra Husada Medan dan Puskesmas Sawit Seberang. Pengabdian masyarakat terkait dengan pemberian Therapy music religi islam melihat banyaknya persalinan yang terlaksana di Puskesmas Sawit Seberang dan yang mayoritas masyarakat muslim.

Pada kegiatan ini dilakukan langkahlangkah yang sistematis berupa : 1. Identifikasi jumlah persalinan normal yang berlangsung. 2 . Melakukan anamnesa pada ibu hamil dalam persalinan Kala I. 3. Memberikan informed consent pada ibu yang akan dilakukan pengabdian masyarakat. 4. Pelaksanaan pemberian therapy music religi islam dalam persalinan kala I dan mensosialisasikan serta memberikan penyuluhan singkat kepada keluarga mengenai therpy yang diberikan.

Sasaran kegiatan ini adalah ibu hamil, ibu persalinan kala I dan keluarga dari ibu dengan melakukan sosialisasi dan penyuluhan singkat mengenai pemberian therapy music religi islam dalam persalinan kala I. religi islammemiliki beberapa kelebihan, yaitu karena musik religi islam bersifat nyaman, menenangkan, membuat rileks, berstruktur dan universal.

Berdasarkan data yang didapatkan dari study pendahuluan yang telah dilakukan di Puskesmas Sawit Seberang tidak ada yang menggunakan terapi musik religi islamdan terapi sedangkan breathing tehnik sering digunakan untuk mengurangi nyeri persalinan. Berdasarkan pengamatan saya sebagai ketua pengabdian masyarakat terhadap bebas, saya sebagai ketua pengabdian masyarakat memilih puskesmas Sawit Seberang yang memiliki potensi untuk diadakan pengabdian masyarakat yang dilakukan tentang efektifitas music.

Untuk itulah saya sebagai ketua pengabdian masyarakat ingin melakukan pengabdian masyarakat yang dilakukan ulang terhadap perbedaan penurunan nyeri persalinan pada ibu inpartu akibat terapi musik religi islam di Puskesmas Sawit Seberang Kecamatan sawit Seberang Kabupaten Langkat.

Bahan alat yang digunakan adalah speaker, music religi islam, lembar observasi.

\section{Hasil}

Pengabdian masyarakat yang dilakukan dilakukan untuk mengamati pengaruh terapi musik religi islam terhadap tingkat nyeri bersalin pada ibu yang bersalin di Puskesmas Sawit Seberang. Pengabdian masyarakat yang dilakukan dilakukan dengan cara mengetahui tingkat awal nyeri bersalin (pretest) sebelum dilakukan terapi musik religi islam kemudian dilanjutkan dengan test akhir (posttest) setelah menggunakan terapi musik religi islam. Adapun hasil pengabdian masyarakat yang dilakukan sebagai berikut :

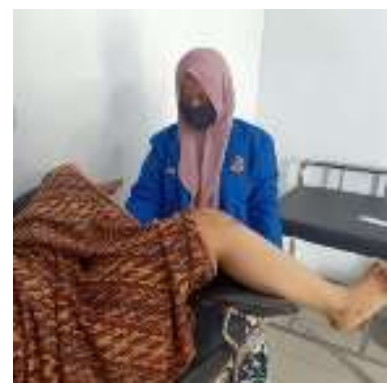

Pemberian theraoy music religi islam saat ibu mulai merasa cemas saat kala I persalinan 


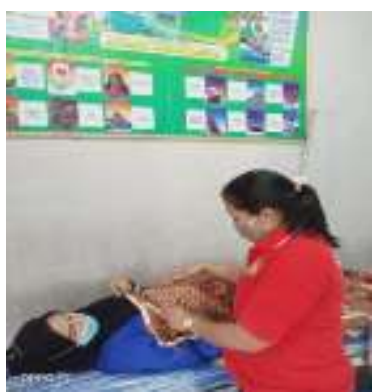

Saat kunjungan ulang kehamilan memberikan sosialisasi tentang therapy music religi islam.

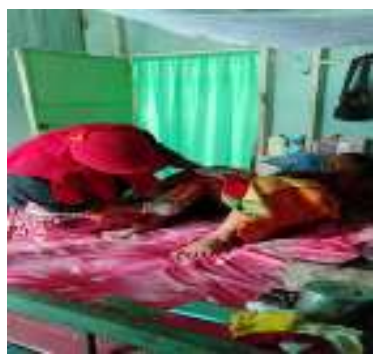

Pemberian theraoy music religi islam saat ibu mulai merasa cemas saat kala I persalinan

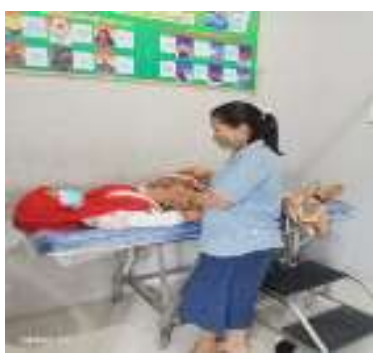

Saat kunjungan ulang kehamilan memberikan sosialisasi tentang therapy music religi islam.

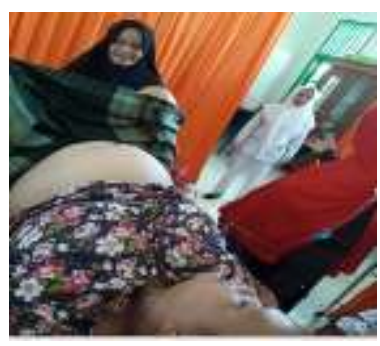

Pemanfaatan therapy music religi islam untuk penurunan kecemasan saat ibu kala I persalinan

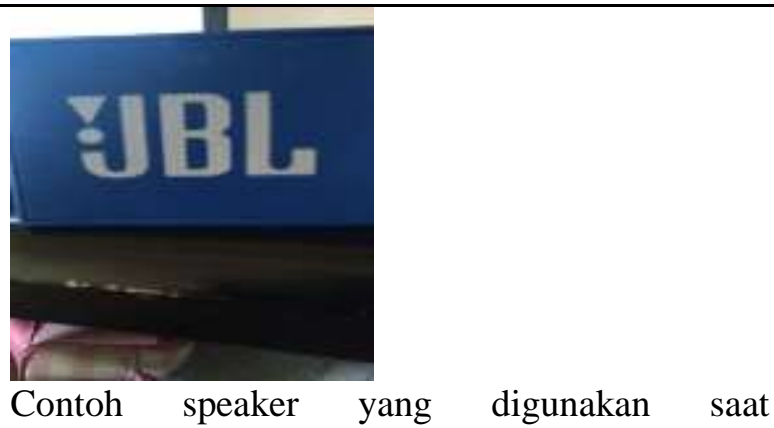
pelaksanaan.

Terapi musik religi islam merupakan salah satu metode untuk teknik relaksasi yang jarang diaplikasikan di dalam praktek keperawatan maternitas, padahal terapi musik religi islammerupakan salah satu teknik distraksi yang efektif yang dapat menurunkan nyeri fisiologi, stress dan nyeri bersalin dengan mengalihkan perhatian seseorang dari nyeri Disamping itu musik religi islamjuga berfungsi sebagai pengontrol dan merupakan teknik untuk menimbulkan kenyamanan lingkungan saat wanita melahirkan diruang bersalin. Music Therapy dapat meningkatkan, memulihkan, dan memelihara kesehatan fisik, mental, emosional, sosial dan spiritual. Hal ini disebabkan musik religi islam memiliki beberapa kelebihan, yaitu karena musik religi islam bersifat nyaman, menenangkan, membuat rileks, berstruktur dan universal.

\section{Kesimpulan}

1. Mengidentifikasi skala nyeri pada kala I fase aktifpemberian terapi music religi islam.

Hasil pengabdian masyarakat yang dilakukan menunjukkan bahwa skala nyeri sebelum Mengidentifikasi penurunan skala nyeri setelah diberikan terapi music.

Hasil pengabdian masyarakat yang dilakukan karena musik religi islam bersifat nyaman, menenangkan, membuat rileks, berstruktur dan universal

2. Menganalisa hasil sosialisasi dan penyuluhan singkat kepada ibu hamil dan keluarga.

Terapi musik religi islammerupakan salah satu metode untuk teknik relaksasi yang jarang diaplikasikan di dalam praktek kesehatan maternitas, padahal terapi musik religi islammerupakan salah satu teknik distraksi yang efektif yang dapat 
menurunkan nyeri fisiologi, stress dan nyeri bersalin dengan mengalihkan perhatian seseorang dari nyeri Disamping itu musik religi islamjuga berfungsi sebagai pengontrol dan merupakan teknik untuk menimbulkan kenyamanan lingkungan saat wanita melahirkan diruang bersalin. Music Therapy dapat meningkatkan, memulihkan, dan memelihara kesehatan fisik, mental, emosional, sosial dan spiritual. Hal ini disebabkan musik religi islam memiliki beberapa kelebihan, yaitu karena musik religi islam bersifat nyaman, menenangkan, membuat rileks, berstruktur dan universal

\section{Saran}

\section{Bagi Ibu hamil dan Bersalin}

Ibu dapat menerapkan tehnik distraksi dengan mendengarkan musik religi islamatau terapi disaat menghadapi persalinan selanjutnya dan ibu bisa mengurangi penggunakan obat-obat yang bisa menimbulkan efek yang kurang baik.

Bagi petugas kesehatan Diharapkan agar bekerjasama dalam memberikan terapi khususnya musik religi islam pada ibu yang memiliki tingkat nyeri bersalin untuk mengurangi nyeri bersalin. Dan dianjurkan kedepan bisa memberikan therapy musik lainnya.

\section{Ucapan Terima Kasih}

Ucapan terima kasih disampaikan kepada STIKes Mitra Husada Medan dan Puskesmas Sawit Seberang karena telah memberikan izin melakukan pengabdian masyarakat yang dilakukan .

\section{Daftar Pustaka}

1. Aryadillah. 2017. Kecemasan Dalam Publik Speaking (Studi kasus Pada Presentasi Makalah Mahasiswa. Vol.XVII,no.2, September 2017

2. Jaya, Kusnadi. 2018. Keperawatan Jiwa. Pamulang: Binarupa Aksara.

3. Johariah dkk. 2017. Asuhan Kebidanan Persalinan dan Bayi baru Lahir. DKI Jakarta.

4. Kementrian Kesehatan RI Pusat Data dan Informasi. 2016. Retrieved April 2019, from http://www.depkes.go.id,
5. Maryunani, Anik. Sukaryati, Yetti. 2018. Senam Hamil, Senam Nifas Dan Terapi Musik. Jakarta: CV. Trans Info Media.

6. Prawirohardjo,S. 2014. Ilmu Kebidanan. Jakarta: Bina Pustaka.

7. Profil Kesehatan Indonesia. 2017. Retrieved April 2019, from http://www.depkes.go.id,

8. Profil Kesehatan Sumatera Utara. 2014. Retrieved April 2019, from http://www.depkes.go.id,

9. Profil Kesehatan Kota Medan. 2016. Retrieved April 2019, from http://www.depkes.go.id

10. Puskesmas Sawit Seberang. (2018). Profil Puskesmas Sawit Seberang 2017. Kecamatan Sawit Seberang

11. Rahmayanty Nina. 2016. Manajeman Pelayanan Prima. Yogyakarta : Graha Ilmu.

12. Rahmita, nurul. 2017. Tingkat Kecemasan pada Ibu Hamil Primigravida Trimester III di Puskesmas Kecamatan Talamanrea Makasar.

13. Riyanto, Agus. 2018. Aplikasi Metode Pengabdian masyarakat yang dilakukan Kesehatan Dilengkapi Contoh Kuesioner Dan laporn Pengabdian masyarakat yang dilakukan. Bandung: Nuha Medika.

14. Rohani dkk, 2016.Asuhan Kebidanan pada Masa Persalinan. Jakarta: Salemba Medika.

15. Rukiyah, Ai Yeyeh, Yulianti, Lia. 2014. Asuhan Kebidanan Kehamilan Berdasarkan kurikulum Berbasis Kompetensi. Jakarta: CV Trans Info Media

16. Sulistyawati Ari dan Nugraheny ESTI.2010. Asuhan Kebidanan Pada Ibu Bersalin. Jakarta: Salemba Medika.

17. Sumarah, dkk. 2010. PERAWATAN IBU BERSALIN (Asuhan Kebidanan Pada Ibu Bersalinan). Yogyakarta: Fitramaya

18. WHO. (2012). Guideline: Daily iron and folic acid supplementation in pregnant women. Geneva, World Health Organization.

http://www.who.int/nutrition/ publications/micronutrients/guidelines/d aily_ifa_supp_pregnant_women/en/ 
19. Ayad Wahyu Utomo dan Agus Santoso. (2013). Studi Pengembangan Terapi Music Islami Sebagai Relaksasi Untuk Lansia, Fakultas Dakwah IAIN Sunan Ampel Surabaya; Vol.03 No.01 